\title{
From extreme rainfall to drought: 250 years of annually resolved sediment deposition in Santa Barbara Basin, California.
}

\author{
Ingrid L. Hendy ${ }^{1 *}$, Tiffany J. Napier ${ }^{1}$, and Arndt Schimmelmann ${ }^{3}$ \\ ${ }^{1}$ Department of Earth and Environmental Sciences, University of Michigan, $1100 \mathrm{~N}$ \\ University Ave., Ann Arbor, MI 48109 (ihendy@umich.edu; tinapier@umich.edu) \\ ${ }^{2}$ Department of Geological Sciences, Indiana University, 1001 E 10th Street, \\ Bloomington, IN 47405-1505 \\ *Corresponding author
}

\section{Abstract}

The Mediterranean climate of southern California is marked by droughts and extreme precipitation events. Here we use elemental variations generated by scanning Xray fluorescence (XRF) to identify droughts and floods in recently deposited (1755-2008 AD) sediments of Santa Barbara Basin (SBB) from box core SPR0901-04BC. The first principal component (PC1) of the scanning XRF elements has high loadings for elements associated with the lithogenic component of SBB laminae couplets, while the second (PC2) is associated with biogenic components. We interpret PC1 as a proxy for river runoff and PC2 as a proxy for marine productivity. High values of PC1 are associated with El Niño events and positive (warm) phases of the Pacific Decadal Oscillation (PDO), while low values of PC2 are associated with El Niño events and negative (cool) phases of the PDO. Droughts such as the 1934-40, 1949-56, and 1989-91 events coincide with low PC1 values. In addition to distinguishing interannual and decadal variability in the elemental composition of SBB sediments, several historic floods can be recognized including a gray flood layer associated with the 1861-62 AD flood, and a peak in PC1 associated with the flood following the St. Francis Dam disaster in 1928 AD. 


\section{Introduction}

Extreme weather events can have a severe impact on society, such that understanding the frequency of these events is critical to disaster management and mitigation planning. In southern California, historical records of extreme weather events are limited by the short duration of settlement in the region. Crucial insight into infrequent, severe weather events can be obtained from paleoclimate reconstructions if the records contain sufficient resolution to preserve weather events rather than climate change. Most paleoclimate reconstructions are limited by the resolution of the proxy records. The well-studied sediments deposited in Santa Barbara Basin (SBB) in southern California are ideal for paleoclimate research. The seasonal climate, high sedimentation rate, coastal upwelling, basin topography, and suboxic bottom water all combine to produce and preserve laminated sediments with high temporal resolution. These laminated sediments enable the reconstruction of interannual climate variability, including extreme floods, and most importantly can extend that reconstruction beyond the historical record (Fleischer, 1972; Rack et al., 1995; Robert, 2004; Schimmelmann and Lange, 1996; Schimmelmann et al., 1998; Soutar and Crill, 1977).

The varve chronology based on annual laminae couplets of the last ca. 300 years can provide the high resolution dating required for such reconstructions, however the validity of a given varve chronology relies on consistent, cyclic, seasonal deposition of the two components that comprise the laminae couplet (Schimmelmann et al., 2013). To produce and preserve annual couplets, these components must be distinct in character, must be deposited during different seasons within the same year, and cannot be mixed by biologic or physical processes (e.g., bioturbation, gravity currents). In SBB the laminae couplets comprise biogenic and terrigenous detrital sediments that are deposited in spring-summer and winter, respectively. Coastal upwelling brings nutrient-rich water to the surface, leading to enhanced primary production and deposition of the biogenic component. The terrigenous detrital component of SBB sediments is transported to the basin by river runoff following winter precipitation events (Fleischer, 1972; Soutar and Crill, 1977; Thunell, 1998; Thunell et al., 1995). Suboxic bottom water inhibits bioturbation, preserving the two seasonal components (Grimm et al., 1996). 
Extreme weather in southern California consists of heavy rainfall from warm-wet storms associated with atmospheric rivers (ARs) that generate flooding (Dettinger, 2004), and drought conditions when winter rains do not arrive. The varve chronology is dependent on cyclic deposition of both components each year. Hendy et al. (2013) demonstrated the loss of annual cyclicity in SBB laminations in some sediment intervals older than 300 years. They hypothesize this loss of annual laminae couplets may be attributable to sedimentary processes that produce and deposit each couplet component responding to changes in climate forcing - those being changes in the annual upwelling cycle that produce the biogenic sediment component, and in the winter delivery of terrigenous detrital sediment from river runoff.

A number of studies have investigated river suspended loads, sediment deposition, and transport processes occurring nearshore and on the shelf in the Southern California Bight (Kolpack and Drake, 1984; Nezlin et al., 2008; Nezlin and Stein, 2005; Thornton, 1984; Warrick et al., 2007; Warrick and Farnsworth, 2009b). Sediment flux from river runoff is a function of storm intensity and precipitation amount (Warrick and Farnsworth, 2009b), therefore varve thickness in SBB sediment is dependent on the amount of rainfall (Soutar and Crill, 1977). These observations suggest that the detrital fraction in SBB sediments may be used as a proxy for precipitation events in southern California. In this study we investigate the terrigenous detrital and biogenic component of sediment in box core SPR0901-04BC (34 ${ }^{\circ} 16.895^{\prime} \mathrm{N}, 120^{\circ} 02.489^{\prime} \mathrm{W}, 588 \mathrm{~m}$ water depth), to characterize the elemental composition and variability of recent SBB sediments from ca. 1755 to 2008 AD. The elemental composition generated through high resolution scanning X-ray fluorescence (XRF) analysis can be used to create an annual record of detrital river input and marine productivity. Here we confirm that the first two principal components of the scanning XRF results are related to the two major components of SBB sediments and demonstrate that extreme precipitation and runoff events, droughts, and changes in marine productivity can be identified through the abundance of chemical elements. Using elemental changes in the laminated sediment, we identify interannual and decadal-scale variability such as El Niño-Southern Oscillation (ENSO) and the Pacific Decadal Oscillation (PDO). 


\section{Regional Setting}

Santa Barbara Basin is located in the Southern California Bight (Fig. 1). Southern California has a semiarid Mediterranean climate with cool winters and hot, dry summers that is moderated by the Pacific High (Nezlin et al., 2005; Nezlin and Stein, 2005; Warrick and Mertes, 2009). In summer, the high-pressure system blocks storm fronts and induces coastal upwelling that brings nutrient-rich water to the surface and stimulates productivity, increasing the biogenic flux to the basin sediments (Lynn and Simpson, 1987; Nezlin et al., 2005; Nezlin and Stein, 2005; Thunell, 1998). The North Pacific High atmospheric pressure system moves southwest in winter, diminishing upwelling and allowing storms to enter the region. Mean annual precipitation in the catchments that discharge into SBB ranges between $30-70 \mathrm{~cm}$, and varies as a function of elevation and orographic effects (Nezlin et al., 2005; Nezlin and Stein, 2005; Warrick and Mertes, 2009). Precipitation from winter storms increases the detrital flux, although the amount of suspended load in the river runoff is influenced by the intervals between rain events, catchment geology and relief, and human modification of the landscape (Inman and Jenkins, 1999; Nezlin and Stein, 2005; Warrick and Mertes, 2009).

The PDO and ENSO also influence southern California's climate (Benson et al., 2003; Dettinger et al., 1998; Inman and Jenkins, 1999; Nezlin and Stein, 2005; Schimmelmann and Tegner, 1991; Warrick and Farnsworth, 2009b; Warrick and Mertes, 2009). The positive (warm) PDO phase is accompanied by increased sea surface temperature (SST) along the west coast of North America, low sea-level pressure in the North Pacific and high sea-level pressure along the western margin of North America (Mantua and Hare, 2002; Miller et al., 1998). The precipitation pattern is similar for both the positive PDO phase and the El Niño phase, with increased precipitation in the American Southwest, including southern California, and decreased precipitation in the Pacific Northwest (Benson et al., 2003). The PDO, which is determined by the first mode of variation of sea surface temperature within the North Pacific $\left(180-110^{\circ} \mathrm{W} ; 25-62^{\circ} \mathrm{N}\right)$, has been implicated in major environmental changes that result in physical-biological regime shifts (Chavez et al., 2003; Di Lorenzo et al., 2008; Mantua et al., 1997). The negative (cool) PDO is associated with intensification of the Aleutian Low and a deepening of the coastal thermocline from California to British Columbia, resulting in 
lower marine productivity on the western margin of North America, while the positive (warm) PDO is associated with higher productivity (Chavez et al., 2003). The North Pacific Gyral Oscillation (NPGO), determined by the second mode of variation of sea surface height in the North Pacific, also correlates to salinity, nutrients, and chlorophyll-a measurements in the California Current System, explaining some observed primary productivity changes not associated with the PDO (Di Lorenzo et al., 2008). PDO regimes persist for 20-30 years, while ENSO events are 6-18 months in duration (Mantua and Hare, 2002). During El Niño events, warm, low nutrient water flows northward from the subtropics and reduces upwelling, diminishing marine productivity in SBB (Venrick, 2012). El Niño events are stronger, more persistent, and more frequent during the positive PDO phase, which results in increased streamflow (Inman and Jenkins, 1999).

The SBB is the offshore extension of the Ventura Basin, and is bounded by the Santa Ynez Mountains to the north, the Channel Islands to the south, and to the east and west by submarine sills. The Santa Clara River catchment is the primary terrigenous sediment source to SBB (Fleischer, 1972; Hein et al., 2003; Kolpack and Drake, 1984; Nezlin et al., 2005; Rack et al., 1995; Robert, 2004). River discharge is ephemeral throughout most of the year, with the average annual sediment load discharged in less than 25 days, but discharge during the wettest years ranges from 8-17\% of the historical average (Warrick and Mertes, 2009; Warrick and Farnsworth, 2009b). Precipitation events generate brief, but intense sediment-laden discharge from the coastal watersheds, followed by influx of suspended sediment from the Ventura, Santa Clara, and Santa Ynez River catchments 1-2 days after the rainstorm event (Nezlin et al., 2005; Warrick et al., 2008). This sediment is dispersed in surface and hyperpycnal plumes and is transported to SBB via floc formation, particle settling, storm wave transport, gravity currents, and mass movement processes (Thornton, 1984, 1986; Warrick and Farnsworth, 2009b; Warrick et al., 2008). A strong relationship between lithogenic sediment and organic carbon in sediment traps deployed in SBB suggests that particle flocculation by marine snow assists the deposition of fine lithogenic particles in the basin during spring-summer (Thunell, 1998). However, extreme precipitation events produce hyperpycnal plumes (Warrick and Milliman, 2003), depositing clay-rich sediments that are preserved as gray flood layers in 
SBB (Fleischer, 1972; Rack et al., 1995; Robert, 2004; Schimmelmann et al., 1998; Thornton, 1984).

\section{Materials and Methods}

\subsection{Scanning X-ray Fluorescence}

The $65 \mathrm{~cm}$ box core, SPR0901-04BC, was scanned with a second generation ITRAX core scanner using a $\mathrm{Cr}$ tube at $200 \mu \mathrm{m}$ intervals for elements $\mathrm{Al}, \mathrm{Br}, \mathrm{Ca}, \mathrm{Cl}, \mathrm{K}$, $\mathrm{Fe}, \mathrm{Mn}, \mathrm{Rb}, \mathrm{S}, \mathrm{Si}, \mathrm{Sr}$, Ti and $\mathrm{Zr}$ at the Large Lakes Observatory, Duluth, MN for 10 seconds per analysis. The $\mathrm{Cr}$ tube was employed in order to increase the count rate of lighter elements such as $\mathrm{Al}$ and $\mathrm{Si}$. The results produced by scanning XRF are output as counts per second per sample location and should thus be considered only semiquantitative (Croudace et al., 2006). Principal component analysis (PCA) of the scanning XRF data was undertaken using the Analyseries 2.0 software (Paillard et al., 1996). Twelve likely correlated variables were converted into a set of linearly uncorrelated variables called principal components, including; $\mathrm{Al}, \mathrm{Si}, \mathrm{Fe}, \mathrm{K}, \mathrm{Ti} \mathrm{Rb}, \mathrm{S}, \mathrm{Cl}, \mathrm{Br} / \mathrm{Cl}$, $\mathrm{Ca} / \mathrm{Ti}, \mathrm{Si} / \mathrm{Ti}$, and $\mathrm{Sr} / \mathrm{Ti}$. Aluminum is near the detection limit of the scanner, such that low counts of this element preclude its use as a normalizing element (Croudace et al., 2006). Titanium, another conservative element that is well resolved by the scanner, was used to normalize for siliciclastic input instead.

\subsection{Quantitative Elemental Analyses}

SPR0901-04BC was sampled continuously at $1 \mathrm{~cm}$ intervals to generate ground bulk samples for additional analyses. Samples were freeze dried and powdered to $<75$ $\mu \mathrm{m}$, and 3-5 g of each powdered sample was sent to ALS Laboratories in Vancouver, Canada for quantitative elemental analysis. Samples were digested with hydrofluoric, nitric, perchloric, and hydrochloric acids. Elemental concentrations of major, minor, and trace elements were determined by inductively coupled plasma-atomic emission spectroscopy (ICP-AES) and inductively coupled plasma-mass spectrometry (ICP-MS). Standard errors are displayed in supplementary Table 1.

Total organic carbon (TOC) and carbonate carbon $\left(\mathrm{CaCO}_{3}\right)$ were determined using paired measurements of acidified and non-acidified sediments. Samples were acidified in $2 \% \mathrm{HCl}$ until all carbonate was removed. Acidified and non-acidified 
samples were dried, powdered, weighed into tin capsules, and measured with a Costech elemental analyzer. Carbon measurements were verified using acetanilide $(C=71.09$ wt. $\%)$ and atropine standards $(\mathrm{C}=70.56 \mathrm{wt} . \%)$, and $20 \%$ sample replication. The standard error of the TOC and $\mathrm{CaCO}_{3}$ replicates was $0.02 \%$ and $0.31 \%$ respectively.

\subsection{Age Model}

The age model for SPR0901-04BC follows the method described by Schimmelmann et al. (1990). The core photograph (supplementary Fig. 1) indicates the distinctive changes in the sedimentary fabric of SBB cores created by the strong El Niño events of 1941, 1957, 1983, and 1997 upon which depths initial age assignments were based. These events (with an error of $\pm \sim 2$ year) were established through varve chronology (Soutar and Crill, 1977), radiometric dating $\left({ }^{210} \mathrm{~Pb}\right)$ (Koide et al., 1972) and excess ${ }^{55} \mathrm{Fe}$ associated with atmospheric bomb fallout between 1962-65 (Krishnas et al., 1973). Schimmelmann et al. (1992) used core-to-core correlation based on porosity and $\mathrm{X}$-radiographs to position this radiometric chronology, generating dates for the gray layer at $1761 \mathrm{AD}$, the turbidite at $1811 \mathrm{AD}$, and the bioturbated Macoma event at $1841 \mathrm{AD}$. These stratigraphic markers can be found in supplementary Fig. 1. Additionally the gray layer at 39 cmbct in supplementary Figure 1was dated as the 1861-62 flood layer. Based on the similarity between the scanning XRF elemental data of SPR0901-04BC and the PDO, the age model was further refined by fixing the peaks and troughs in PC1 to the positive and negative PDO cycles within the constraints of the varve chronology employing the Analyseries software (Paillard et al., 1996) linage tool. The tie points between PC1 and the PDO are displayed in supplementary Table 2.

Due to core compaction during the 3 years between scanning XRF analysis and bulk sediment sampling, quantitative elemental analyses results were fitted to scanning XRF results through a depth correction shown in Fig. 2. Ages were then assigned to the bulk sediment samples using the age model described above (Fig. 3).

\section{Results}

\subsection{Elemental analyses}

XRF core scanners provide rapid, non-destructive, high-resolution $(200 \mu \mathrm{m})$ elemental analyses of sediment and have been particularly successful in paleoclimate reconstructions where the relative input of biogenic and terrigenous detrital components 
drives element variability in sediments (e.g. Arz et al., 2001; Brown et al., 2007; Donnelly and Woodruff, 2007; Grutzner et al., 2003; Haug et al., 2003; Jahn et al., 2003; Lamy et al., 2001; Lamy et al., 2004; Norris and Rohl, 1999; Peterson et al., 2000; Rohl et al., 2000; Tierney et al., 2005). Titanium and Fe are commonly attributed to terrigenous inputs in pelagic and hemipelagic sediments and thus have been used as proxies for river runoff and precipitation (Peterson and Haug, 2006). In Fig. 4, scanning XRF analysis of SPR0901-04BC demonstrates high counts of Ti and Fe during wet years associated with El Niño events, alongside other elements associated with siliciclastic sediments such as K, Al, Si, and Rb, and low counts during drought intervals (e.g. 19341940, 1949-1956, and 1989-1991). However, other processes also affect elemental distributions in sediments. Suboxic bottom waters in SBB complicate interpretation of Fe concentrations, as oxidized iron species are reduced to form pyrite and greigite (Blanchet et al., 2009). Calcium is abundant in SBB terrigenous sediment sources, but it is also a component of biogenic carbonate; therefore this input must also be considered.

The lower resolution, bulk sediment ICP-AES and -MS analyses yielded elemental concentrations that are consistent with the scanning XRF counts, supporting the accuracy of the scanning XRF counts in capturing relative elemental variations in this core. Elemental concentrations increase in sediments associated with wet years, and decrease in sediments deposited during dry years, recording instrumental and historical droughts, El Niño events, and extreme floods (Fig. 4). However absolute elemental concentrations are not consistent between hydroclimatic extremes. The highest detrital elemental concentrations are associated with the two gray layers in the core (1861-62 and 1761 flood events). Between the 1811 turbidite and the 1842 Macoma layer, corresponding to the massive olive layer seen in the core photograph scanning XRF counts and quantitative ICP-MS concentrations are relatively uniform (supplementary Fig. 1).

\subsection{Biogenic sediment components}

Calcium carbonate, TOC, and biogenic silica dominate the biogenic component of $\mathrm{SBB}$ sediment. TOC is compared to the $\mathrm{Br} / \mathrm{Cl}$ elemental ratio as $\mathrm{Br}$ concentrations are fundamentally controlled by TOC content of sediments (Price and Calvert, 1977). The bromide ion $\left(\mathrm{Br}^{-}\right)$is the principal bromine species in seawater irrespective of the redox 
potential and is associated with TOC in many depositional environments (Leri et al., 2010). The scanning XRF counts were normalized to chlorine to account for the contribution of porewater $\mathrm{Br}^{-}$to the scan counts. TOC is lowest $(0.5-0.7$ wt. \%) in the gray layers and the massive olive layer, and highest ( $4.5 \mathrm{wt} . \%)$ immediately before 1969 (Fig. 5A). Br/Cl also displays the lowest values in the gray layers and the massive olive layer, but the highest value occurs during the bioturbated Macoma interval.

Differences observed between the two methods of measuring organic matter may relate to changes in porewater chemistry and the origin of the organic matter being deposited in the basin. For example the 1969 Santa Barbara oil spill released hydrocarbon-rich organic matter into the basin that left an isotopic signature in the organic sediments of SBB (Schimmelmann and Kastner, 1993), which could explain the highest TOC values in SPR0901-04BC.

Calcium enrichment beyond the lithogenic component of sediment should be associated with biogenic precipitation of $\mathrm{CaCO}_{3}$ by marine organisms such as foraminifera, coccolithophorids, and bivalves such as Macoma. Titanium was used to normalize the bulk elemental chemistry because $\mathrm{Al}$ as the most frequently employed lithogenic element is not well resolved by the scanning XRF method. Similar to Al, Ti is not associated with biological activity or precipitated authigenically. The excess $\mathrm{Ca}$ normalized to Ti in the scanning XRF counts is low and follows ICP-AES and -MS generated $\mathrm{Ca} / \mathrm{Ti}$ and calculated $\mathrm{CaCO}_{3}$ from the bulk samples. $\mathrm{CaCO}_{3}$ is close to $0-1 \mathrm{wt}$. $\%$ in the gray layers, the massive olive layer, and between 1885-1910 and 1965-1980 (Fig. 5B). The highest concentration of $\mathrm{CaCO}_{3}$ ( $\sim$ wt. \%) occurs at $\sim 1780,1805,1840$. Some differences are observed between the three methods of determining the biogenic production of carbonate. $\mathrm{CaCO}_{3}$ is high at the base of the massive olive layer where high concentrations of benthic foraminifera are observed, while $\mathrm{Ca} / \mathrm{Ti}$ remains low. High $\mathrm{Ca} / \mathrm{Ti}$ relative to $\mathrm{CaCO}_{3}$ from 1870 to 1910 may be the result of relatively higher Ca compared to Ti delivered to the basin due to a mineralogical change in the lithogenic component of runoff sediment.

\subsection{Principal Component Analysis}

Principal component analysis was used to reduce the influence of multiple source inputs and post-depositional processes in the scanning XRF analyses. A selection of 
elements and elemental ratios was used, incorporating three possible input sources; siliciclastic sediment (Al, Fe, K, Rb, Si and Ti); biogenic sediment ( $\mathrm{Br} / \mathrm{Cl}, \mathrm{Si} / \mathrm{Ti}, \mathrm{Ca} / \mathrm{Ti}$ and $\mathrm{Sr} / \mathrm{Ti})$; and porewater ( $\mathrm{Cl}$ and $\mathrm{S})$. The first principal component accounts for the largest amount of variability in the data. The first principal component (PC1) explains $45.5 \%$ of the elemental variance in SPR0901-04BC, and has high loadings for elements associated with siliciclastic sediment including Al, Fe, K, Rb, Si and Ti (Fig. 4F; Hendy et al., 2004). The second principal component (PC2) explains $16.5 \%$ of the variance and has high loadings for ratios associated with biogenic sediment (Fig. 5C). These include $\mathrm{Ca} / \mathrm{Ti}$ and $\mathrm{Sr} / \mathrm{Ti}$, which are associated with $\mathrm{CaCO}_{3}$-producing organisms such as foraminifera and coccolithophorids, $\mathrm{Si} / \mathrm{Ti}$ associated with biogenic silica, and $\mathrm{Br} / \mathrm{Cl}$ associated with organic matter (Fig. 5C; Hendy et al., 2004). The full array of principal components is displayed in supplementary Table 3 and an ordination diagram of the first two principal components is displayed in supplementary Fig. 2.

Thus in SBB sediments, the first two principal components jointly explain $62 \%$ of the scanning XRF data variance and identify two major sediment inputs in the basin: the mineral or siliciclastic fraction of the terrigenous detrital component, and the biogenic component including organic carbon, $\mathrm{CaCO}_{3}$, and biogenic silica. In this contribution we interpret PC1 as an indicator of the terrigenous detrital sediment delivery to the basin via river runoff and PC2 as marine productivity. Consequently, high PC1 scores follow observed high rainfall events, with high scores associated with El Niño events and gray flood layers, and low PC1 scores correspond to drought conditions (Fig. 4).

\section{Discussion}

In order to verify that the laminated sediments of SBB can provide a record of annual changes in precipitation and primary productivity, we need to determine if the annual record of terrigenous detrital sediment input has a relationship with interannual variability. What is the relationship between different sediment components in SBB laminae and ENSO and PDO?

\subsection{A new annual record of river runoff}

Many paleoclimate studies in SBB assume there is a robust annual signal in sediment deposition, and the novel application of scanning XRF analysis to SBB sediments confirms this assumption. Terrigenous detrital sediment delivered by river 
runoff has a strong annual signal as river flow is driven by winter rainfall events. SBB sediment trap studies show the lithogenic component of sediments comprises 50-75 wt. $\%$ of the dry sediment delivered during a year (Thunell, 1998). Biological productivity in the basin is strongly influenced by spring-summer upwelling. Biogenic sediment components, biogenic silica, $\mathrm{CaCO}_{3}$, and TOC make 10-30, 5-15 and 3-5 wt. \% of the sediment delivered, respectively (Heusser et al., in press; Thunell, 1998). Thus with a sampling rate of $\sim 7$ analyses per year, annual variability is clearly recorded in the elemental composition of SBB laminated sediments through much of the last 250 years. However, due to interannual variability such as ENSO, half of the suspended sediment discharge from rivers in southern California occurs in one day every three years (Warrick and Milliman, 2003), resulting in pulsed lithogenic sediment input associated with heavy precipitation events. Thus El Niño years associated with high precipitation and low productivity are reproduced by high scores for PC1 and low PC2 scores for that year.

The delivery of detrital sediment to the basin from rivers has been the focus of numerous studies in recent years that have improved our understanding of coastal processes (Nezlin et al., 2008; Warrick et al., 2007; Warrick and Farnsworth, 2009a; Warrick and Mertes, 2009). A relationship between lithogenic material and TOC in SBB sediment traps suggests that terrestrial detritus may be delivered to the sea floor via marine snow flocculation in spring-summer (Thunell, 1998). However, observed hyperpycnal (negatively buoyant) sediment gravity currents that form rapidly after stormdriven peak river discharge provide a more direct delivery mechanism for terrestrial detritus (Warrick et al., 2008). During the El Niño-related floods of 1998, only a small portion of the flood-suspended load was surficial, leaving the remainder to be delivered to the basin by subsurface density-driven flow (Mertes and Warrick, 2001). As the fate of sediments delivered by hyperpycnal currents is controlled by basin bathymetry rather than currents as with suspended sediment (Warrick et al., 2008), the location of SPR0901-04BC closer to the shelf has likely created the more distinct record of gray layers compared to other studies (Field et al., 2006; Schimmelmann et al., 1992; Soutar and Crill, 1977), including the 1861-62 gray layer flood and the flood following the St. Francis Dam disaster of 1928. These significant sedimentation events display continued high PC1 values in the years following the flood sediment deposition, suggesting that the 
deposition of terrestrial detritus on the shelf of the basin provides a source of sediment that can be resuspended by waves in the following years and redeposited in the center of the basin independently of further river runoff.

A $0.5 \mathrm{~cm}$ thick gray layer located above the Macoma event (1841) in SPR090104BC is likely the deposit associated with the 1861-62 flood. The flood was associated with a series of probable atmospheric rivers (ARs) (Dettinger and Ingram, 2013) on the $9^{\text {th }}$ and $23-28^{\text {th }}$ of December, 1861, and 9-12 $2^{\text {th }}$ and $15-17^{\text {th }}$ of January, 1862 (Newbold, 1991) with $168 \mathrm{~cm}$ of rain falling in Los Angeles, and resulting in extensive flooding in Oregon, Nevada, Arizona, and California, notably in California's Central Valley (Engstrom, 1996; Ingram, 2013). The flood event had an unparalleled impact on the state economy. The loss of property tax revenue left the State of California bankrupt in 1862 and the governor, state legislature, and state employees were not paid for 1.5 years (Brewer, 1930). The event brought about the decline of ranching in California as $\sim 200,000$ thousands of cattle drowned, and recovery was thwarted by severe drought in the following years (Burcham, 1957). The unofficial total rainfall for the winter of 186162 is three times greater than any precipitation event recorded in Santa Barbara in the last 100 years. In the Santa Barbara region, flooding resulted in the infilling of the deep water moorage in Goleta Slough (Fig. 1), with silt and debris washed out of the Santa Ynez Mountains (Griggs and Russell, 2012). The 1861-62 flood layer is the most recent gray layer in a stratigraphic sequence of flood events found in SBB that occur during the Holocene every 200 years (Schimmelmann et al., 2006).

Not every flood event stems from natural causes. The St. Francis Dam built in the San Francisquito Valley (Fig. 1) on a tributary of the Santa Clara River failed catastrophically upon its first filling on the night of March 12-13, 1928, killing 450 people downstream in the Santa Clara catchment (Rogers, 1995). Forty two billion liters of water emptied into the Santa Clara River, overflowing the banks with a $17 \mathrm{~m}$ surge, and flooding the Santa Clara floodplain. In less than 6 hours, the flood reached the coast carrying debris in a two km wide swath across the floodplain (Rogers, 1995). A peak in PC1 and a thick varve similar to peaks corresponding to large El Niño events such as 1997 and 1983 was originally assigned to the closest El Niño year 1931 with significant precipitation (Schimmelmann et al., 1992). Given the $\sim 3$ year error of the varve 
chronology at that depth in core (Soutar and Crill, 1977), and the observation of a flood (not related to climate), this varve is likely to be 1928. Additionally, slumping was found beneath the 1928 varve by Koide et al. (1972) suggesting sediment disturbance occurred elsewhere in the basin. PC1 remains high during the following three years suggesting that sediment from the shelf continued to be reworked into the basin by wave activity.

\subsection{Interannual climate variability and sedimentary deposition in Santa Barbara Basin}

Wet and dry intervals in southern California are associated with interannual climate variability (e.g., PDO and ENSO), which directly influence river sediment fluxes, with higher (lower) annual sediment flux during wet (dry) periods (Soutar and Crill, 1977; Inman and Jenkins, 1999; Nezlin and Stein, 2005; Warrick and Farnsworth, 2009b). Warrick and Milliman (2003) found 90\% of historic river sediment loads occurred during El Niño years, although not every El Niño was marked by heavy precipitation. This relationship is related to California's Mediterranean climate that generally produces either flooding or drought, but rarely average conditions (Dettinger et al., 2011). Recent satellite observations have linked severe flooding in California with AR or low level jets on the frontal edge of winter cyclones that draw moisture and warm air from the tropics (near Hawaii) to the west coast of North America (Neiman et al., 2008; Ralph et al., 2004). Extrapolating from the observation that 1861-62 flood (gray layer) was generated by an AR, every preceding gray layer in the SBB sequence is assumed to be associated with one (Dettinger and Ingram, 2013).

As anticipated given aforementioned observations, the most prominent peaks in PC1 values coincide with El Niño events (i.e. 1902, 1931-32, 1941-42, 1951-52, 195657, 1978-79, 1982-83, 1993, 1997-98; Fig. 6). Not every El Niño is associated with a PC1 peak however, and these 'missing' events often occur during intervals of negative (cool) PDO. Multiyear high PC1 values occur during intervals of positive (warm) PDO. High PC1 values maybe amplified by low PC2 values as El Niño events are associated with warming of SSTs in the eastern Pacific and a coincident deepening of the thermocline, resulting in decreased primary productivity and/or a shift in marine ecosystem (Miller et al., 2004). Short duration low PC2 values are observed at many El Niño events, including those previously mentioned, however, multiyear low PC2 values coincide with negative (cool) PDO and higher frequency El Niño events. Another 
limitation with PC2 as an indicator of primary productivity in SBB is the impact of changing preservation on TOC concentrations. Notably Schimmelmann and Kastner (1993) demonstrated that gray layer deposition has a 'coffin lid' effect on TOC degradation such that TOC is better preserved and therefore more concentrated directly below a clay-rich flood event.

In addition to identifying significant precipitation events in the historic record, PC1 values also decrease during known drought intervals that are often associated with La Niña years. In particular the droughts of 1949-56 and 1989-91 are highlighted by low PC1 values, while the dustbowl years (1934-1940) show little variability in PC1 (Fig. 6). The drought of the 1950's has been associated with cool sea surface temperatures in the eastern Pacific during an interval of negative (cool) PDO, while the drought of the 1930's is suggested to have a different origin (Cook et al., 2010). In SPR0901-04BC the low values of PC1 during the 1950's and from 1989-91 coincide with a negative (cool) PDO and El Niño events are less common in the 1940's and 50's. Thus the sedimentary record in SBB supports the contention that El Niño and AR's are 'drought busters' in California (Dettinger and Ingram, 2013; Dettinger, 2013; Ward et al., 2014).

We propose that high PC1 values could be used as a proxy for positive (warm) PDO and El Niño events beyond the historical record based on the $20^{\text {th }}$ century record in SBB, with some caveats. ENSO can amplify or mute the PDO signal in PC1 through sediment dilution as primary productivity decreases during El Niño events (amplifying PC1) but increases during positive (warm) PDO (muting PC1). Significant flood events can deliver detrital sediments to the continental shelf that may be reworked during subsequent wave activity. Large wave heights may be produced distally from SBB creating increased PC1 values unrelated to local weather events. However, waves can only enter the Santa Barbara Channel from the northwest or east. Increased wave activity or detrital sediment storage on the shelf may mask drought conditions by continuing to supply sediment to the basin center in the absence of river runoff events Finally PC1 is ideally a proxy for river runoff and as such only heavy rainfall events that generate runoff will be recorded.

\section{Conclusions}


The laminated sediments of Santa Barbara Basin have long been used to create high resolution paleoclimate reconstructions. Here we demonstrate that XRF core scanning technology can capture extreme weather events in addition to interannual and decadal climate variability. Comparison of scanning XRF counts to ICP-MS elemental concentrations demonstrated that variations in major elemental relative abundances are accurately measured in recently collected box core sediments (SPR0901-04BC). Additionally $\mathrm{Ca} / \mathrm{Ti}$ and $\mathrm{Br} / \mathrm{Cl}$ elemental ratios can be used as tracers of carbonate and total organic matter, respectively. The first principal component (PC1) of the scanning XRF elemental suite captures elements associated with siliciclastic sediment and therefore the lithogenic component of SBB varved sediments. The lithogenic component likely originates as terrestrial detritus transported to SBB during precipitation events via river runoff. PC1 captures recorded precipitation events including El Niños and extreme floods, as well as periods of drought, and therefore high PC1 values may be used as an indicator of positive (warm) Pacific Decadal Oscillations (PDO) and/or El Niño events in the paleorecord, as these interannual and decadal scale climate variations impact river runoff. $\mathrm{PC} 2$ captures ratios (e.g., $\mathrm{Br} / \mathrm{Cl}, \mathrm{Ca} / \mathrm{Ti}$ and $\mathrm{Si} / \mathrm{Ti}$ ) associated with marine productivity and shows low values during El Niño events and negative (cool) PDO.

Historic flood events are recorded in the first principal component (PC1) of SPR0901-04BC demonstrating the utility of the scanning XRF method in paleoprecipitation reconstructions. The 1861-62 flood event is recorded for the first time as a $0.5 \mathrm{~cm}$ thick massive gray layer possibly as SPR0901-04BC is sited closer to the shelf. This event was associated with significant sediment-rich discharge as it infilled the deepwater moorage of Goleta Slough with silt and debris. The St. Francis Dam disaster of 1928 is also recorded in SPR0901-04BC as high PC1 values during an interval of relatively small precipitation events. High PC1 values are recorded for several years following these flood events, suggesting that major precipitation events deposit sediment on the shelf that can be reworked in later years by wave activity. Sediment reworking may therefore limit the detection of droughts in years following major runoff events or increased wave activity. 


\section{Acknowledgements}

This work is supported by the National Science Foundation under grant number OCE-0752093 and OCE-1304327 awarded to IH and by the Rackham Graduate School of the University of Michigan awarded to TN, and by National Science Foundation grant OCE-0752068 to AS. We would like to acknowledge the crew of the R/V Robert Gordon Sproul for assistance in collecting core material. Acknowledgement is made to Timothy Gallagher and Allyson Tessin for their aid in preparation and extraction of carbon data. 


\section{Figure Captions}

Figure 1. Map of the Santa Barbara Basin showing the location of box core SPR090104BC and Ocean Drilling Program (ODP) Site 893. Topography and bathymetry are in $100 \mathrm{~m}$ increments. Thick black lines indicate river catchments and thin blue lines represent rivers draining into Santa Barbara Basin.

Figure 2. Depth correlation between the bulk sediment ICP-MS Ca/Ti (thick red line) and $\mathrm{Ti}(\%)$ (thick black line) and scanning XRF Ca/Ti (thin pink line) and Ti counts (thin gray line) for box core SPR0901-04BC. Gray lines represent tie points with ICP-MS sample depth. Ratios represent the relative change in depth between the two records as a result of core compaction and bulk sediment sampling precision.

Figure 3. Age correlation between the bulk sediment ICP-MS Ca/Ti (thick red line) and Ti (\%) (thick black line) and scanning XRF Ca/Ti (thin pink line) and Ti counts (thin gray line) record for box core SPR0901-04BC. Gray lines represent age points between the ICP-MS and scanning XRF samples.

Figure 4. Comparison of XRF counts per second (cps) and bulk sediment elemental concentrations. (A) ICP-MS Al ( wt. \%, thick black line) and the 10-pt moving average of the scanning XRF Al cps (thin black line); (B) ICP-MS Fe (wt. \%, thick red line) and scanning XRF Fe cps (thin red line); (C) ICP-MS K (wt. \%, thick green line) and scanning XRF K cps (thin green line); (D) ICP-MS Rb (wt. ppm, thick purple line) and the 10-pt moving average of the scanning XRF Rb cps (thin purple line); (E) ICP-MS Ti (wt. \%, thick blue line) and scanning XRF Ti cps (thin blue line); (F) the first principal component of the scanning XRF cps (thick black line). Selected El Niño events (1902, 1940-41, 1957-58, 1969-70, 1982-83 and 1997-98) are indicated by blue lines (Climate Prediction Center Internet Team, 2014; Quinn and Neal, 1992). Gray layers are represented by gray shading, while the massive olive layer is indicated with tan shading. Droughts are represented by red horizontal bars. 
Figure 5. Comparison between bulk sediment. (A) total organic carbon (wt. \%, TOC; thick green line) and scanning XRF Br/Cl (thin green line); (B) Scanning XRF Ca/Ti (thin pink line), ICP-MS Ca/Ti (thick red line) and $\mathrm{CaCO} 3 \%$ (thick black line); (C) 10-pt moving average of the second principal component (PC2) of the scanning XRF elements (thin black line). Selected El Niño events (1902, 1940-41, 1957-58, 1969-70, 1982-83 and 1997-98) are displayed by blue lines (Climate_Prediction_Center_Internet_Team, 2014; Quinn and Neal, 1992). Gray layers are represented by gray shading, while the massive olive layer is indicated by tan shading.

Fig. 6. Comparison between the first two principal components of box core SPR090104BC scanning XRF elements, El Niño-Southern Oscillation (ENSO), and Pacific Decadal Oscillation (PDO) in the North Pacific. (A) PDO index (ERSST ver. 3); (B) first principal component (PC1) of scanning XRF elements (lithogenic component of the sediments); (C) ENSO (Climate Prediction Center Internet Team, 2014); (D) 10-pt moving average of second principal component (PC2) of scanning XRF elements (biogenic component of the sediments). Gray layers are represented by gray shading, while the massive olive layer is indicated by tan shading. Selected El Niño events (1902, 1940-41, 1957-58, 1969-70, 1982-83 and 1997-98) are displayed by blue lines. Droughts are represented by red horizontal bars. 


\section{References}

Arz, H.W., Gerhardt, S., Patzold, J., Rohl, U., 2001. Millennial-scale changes of surface- and deep-water flow in the western tropical Atlantic linked to Northern Hemisphere high-latitude climate during the Holocene. Geology 29, 239-242.

Benson, L., Linsley, B., Smoot, J., Mensing, S., Lund, S., Stine, S., Sarna-Wojcicki, A., 2003. Influence of the Pacific Decadal Oscillation on the climate of the Sierra Nevada, California and Nevada. Quat. Res. 59, 151-159.

Blanchet, C.L., Thouveny, N., Vidal, L., 2009. Formation and preservation of greigite (Fe3S4) in sediments from the Santa Barbara Basin: Implications for paleoenvironmental changes during the past $35 \mathrm{ka}$. Paleoceanography 24.

Brewer, W.H., 1930. Up and down California in 1860-1864; The Journal of William H. Brewer. Yale University Press, New Haven.

Brown, E.T., Johnson, T.C., Scholz, C.A., Cohen, A.S., King, J.W., 2007. Abrupt change in tropical African climate linked to the bipolar seesaw over the past 55,000 years. Geophysical Research Letters 34.

Burcham, L.T., 1957. California range land: an historico-ecological study of the range resource of California. Division of Forestry, Dept. of Natural Resources, Sacramento.

Chavez, F.P., Ryan, J., Lluch-Cota, S.E., Niquen, M., 2003. From anchovies to sardines and back: Multidecadal change in the Pacific Ocean. Science 299, 217-221.

Climate Prediction Center Internet Team, 2014. Historical El Nino/ La Nina episodes (1950-present). NOAA Center for Weather and Climate Prediction, Maryland.

Cook, E.R., Seager, R., Heim, R.R., Vose, R.S., Herweijer, C., Woodhouse, C., 2010. Megadroughts in North America: placing IPCC projections of hydroclimatic change in a long-term palaeoclimate context. Journal of Quaternary Science 25, 48-61.

Croudace, I.W., Rindby, A., Rothwell, R.G., 2006. ITRAX: description and evaluation of a new multifunction X-ray core scanner, In: Rothwell, R.G. (Ed.), New Techniques in Sediment Core Analysis. Geological Society of London, London, pp. 51-63.

Dettinger, M., Ingram, B., 2013. The coming megafloods. Scientific American 398, 64-71.

Dettinger, M.D., 2004. Fifty-two years of "pineapple-express" storms across the West Coast of North America California Energy Commission, Public Interest Energy Research Energy-Related Environmental Research, US Geological, Survey, Scripps Institution of, Oceanography, [Sacramento, Calif.].

Dettinger, M.D., 2013. Atmospheric Rivers as Drought Busters on the US West Coast. Journal of Hydrometeorology 14, 1721-1732.

Dettinger, M.D., Cayan, D.R., Diaz, H.F., Meko, D.M., 1998. North-south precipitation patterns in western North America on interannual-to-decadal timescales. Journal of Climate 11, 3095-3111. 
Dettinger, M.D., Ralph, F.M., Das, T., Neiman, P.J., Cayan, D.R., 2011. Atmospheric Rivers, Floods and the Water Resources of California. Water 3, 445-478.

Di Lorenzo, E., Schneider, N., Cobb, K.M., Franks, P.J.S., Chhak, K., Miller, A.J., McWilliams, J.C., Bograd, S.J., Arango, H., Curchitser, E., Powell, T.M., Riviere, P., 2008. North Pacific Gyre Oscillation links ocean climate and ecosystem change. Geophysical Research Letters 35.

Donnelly, J.P., Woodruff, J.D., 2007. Intense hurricane activity over the past 5,000 years controlled by El Nino and the West African monsoon. Nature 447, 465-468.

Engstrom, W.N., 1996. The California storm of January 1862. Quat. Res. 46, 141-148.

Field, D.B., Baumgartner, T.R., Charles, C.D., Ferreira-Bartrina, V., Ohman, M.D., 2006. Planktonic foraminifera of the California Current reflect 20th-century warming. Science 311, 63-66.

Fleischer, P., 1972. Mineralogy and sedimentation history, Santa Barbara Basin, California. Journal of Sedimentary Petrology 42, 49-58.

Griggs, G., Russell, N., 2012. City of Santa Barbara sea-level rise vulnerability study In: Commission, C.E. (Ed.). California Energy Commission's California Climate Change Center.

Grimm, K.A., Lange, C.B., Gill, A.S., 1996. Biological forcing of hemipelagic sedimentary laminae: Evidence from ODP Site 893, Santa Barbara Basin, California. Journal Of Sedimentary Research 66, 613-624.

Grutzner, J., Rebesco, M.A., Cooper, A.K., Forsberg, C.F., Kryc, K.A., Wefer, G., 2003. Evidence for orbitally controlled size variations of the East Antarctic Ice Sheet during the late Miocene. Geology 31, 777-780.

Haug, G.H., Gunther, D., Peterson, L.C., Sigman, D.M., Hughen, K.A., Aeschlimann, B., 2003. Climate and the collapse of Maya civilization. Science 299, 1731-1735.

Hein, J.R., Dowling, J.S., Schuetze, A., Lee, H.J., 2003. Clay-mineral suites, sources, and inferred dispersal routes: Southern California continental shelf. Marine environmental research 56, 79-102.

Hendy, I.L., Dunn, L., Schimmelmann, A., Pak, D.K., 2013. Resolving varve and radiocarbon chronology differences during the last 2000 years in the Santa Barbara Basin sedimentary record, California. Quaternary International 310, 155-168.

Hendy, I.L., Pedersen, T.F., Kennett, J.P., Tada, R., 2004. Intermittent existence of a southern Californian upwelling cell during submillennial climate change of the last 60 kyr. Paleoceanography 19 , PA3007.

Heusser, L.E., Hendy, I.L., Barron, J.A., in press. Vegetation response to southern California drought during the Medieval Climate Anomaly and early Little Ice Age (AD 800-1600). Quaternary International.

Ingram, B.L., 2013. California Megaflood: Lessons from a Forgotten Catastrophe. Scientific American.

Inman, D.L., Jenkins, S.A., 1999. Climate change and the episodicity of sediment flux of small California rivers. Journal Of Geology 107, 251-270. 
Jahn, B., Donner, B., Muller, P.J., Rohl, U., Schneider, R.R., Wefer, G., 2003. Pleistocene variations in dust input and marine productivity in the northern Benguela Current: Evidence of evolution of global glacial-interglacial cycles. Palaeogeography Palaeoclimatology Palaeoecology 193, 515533.

Koide, M., Soutar, A., Goldberg, E.D., 1972. Marine geochronology with ${ }^{210} \mathrm{~Pb}$. Earth Planet. Sci. Lett. 14, 442-446.

Kolpack, R.L., Drake, D.E., 1984. Transport of clays in the eastern part of Santa Barbara Channel, California. Geo-Marine Letters 4, 191-196.

Krishnas, S., Lal, D., Amin, B.S., Soutar, A., 1973. Geochronological studies in Santa Barbara Basin - Fe as a unique tracer for particulate settling. . Limnology and Oceanography 18, 763-770.

Lamy, F., Hebbeln, D., Rohl, U., Wefer, G., 2001. Holocene rainfall variability in southern Chile: a marine record of latitudinal shifts of the Southern Westerlies. Earth Planet. Sci. Lett. 185, 369-382.

Lamy, F., Kaiser, J., Ninnemann, U., Hebbeln, D., Arz, H.W., Stoner, J., 2004. Antarctic timing of surface water changes off Chile and Patagonian ice sheet response. Science 304, 1959-1962.

Leri, A.C., Hakala, J.A., Marcus, M.A., Lanzirotti, A., Reddy, C.M., Myneni, S.C.B., 2010. Natural organobromine in marine sediments: New evidence of biogeochemical Br cycling. Global Biogeochemical Cycles 24.

Lynn, R.J., Simpson, J.J., 1987. The California Current System - The Seasonal Variability Of Its Physical Characteristics. Journal of Geophysical Research-Oceans 92, 12947-12966.

Mantua, N.J., Hare, S.R., 2002. The Pacific decadal oscillation. Journal of Oceanography 58, 35-44.

Mantua, N.J., Hare, S.R., Zhang, Y., Wallace, J.M., Francis, R.C., 1997. A Pacific interdecadal climate oscillation with impacts on salmon production. Bulletin Of The American Meteorological Society 78, 1069-1079.

Mertes, L.A.K., Warrick, J.A., 2001. Measuring flood output from 110 coastal watersheds in California with field measurements and SeaWiFS. Geology 29, 659-662.

Miller, A.J., Cayan, D.R., White, W.B., 1998. A westward-intensified decadal change in the North Pacific thermocline and gyre-scale circulation. Journal of Climate 11, 3112-3127.

Miller, A.J., Chai, F., Chiba, S., Moisan, J.R., Neilson, D.J., 2004. Decadal-scale climate and ecosystem interactions in the North Pacific Ocean. Journal of Oceanography 60, 163-188.

Neiman, P.J., Ralph, F.M., Wick, G.A., Kuo, Y.H., Wee, T.K., Ma, Z.Z., Taylor, G.H., Dettinger, M.D., 2008. Diagnosis of an Intense Atmospheric River Impacting the Pacific Northwest: Storm Summary and Offshore Vertical Structure Observed with COSMIC Satellite Retrievals. Monthly Weather Review 136, 4398-4420.

Newbold, J.D., 1991. The Great California Flood of 1861-1862 San Joaquin Historian 5.

Nezlin, N.P., DiGiacomo, P.M., Diehl, D.W., Jones, B.H., Johnson, S.C., Mengel, M.J., Reifel, K.M., Warrick, J.A., Wang, M.H., 2008. Stormwater plume detection by MODIS imagery in the southern California coastal ocean. Estuarine Coastal and Shelf Science 80, 141-152. 
Nezlin, N.P., DiGiacomo, P.M., Stein, E.D., Ackerman, D., 2005. Stormwater runoff plumes observed by SeaWiFS radiometer in the Southern California Bight. Remote Sensing of Environment 98, 494510.

Nezlin, N.P., Stein, E.D., 2005. Spatial and temporal patterns of remotely-sensed and field-measured rainfall in southern California. Remote Sensing of Environment 96, 228-245.

Norris, R.D., Rohl, U., 1999. Carbon cycling and chronology of climate warming during the Palaeocene/Eocene transition. Nature 401, 775-778.

Paillard, D., Labeyrie, L., Yiou, P., 1996. Macintosh Program Performs Time-Series Analysis EOS Transactions. American Geophysical Union, p. 379.

Peterson, L.C., Haug, G.H., 2006. Variability in the mean latitude of the Atlantic Intertropical Convergence Zone as recorded by riverine input of sediments to the Cariaco Basin (Venezuela). Palaeogeography Palaeoclimatology Palaeoecology 234, 97-113.

Peterson, L.C., Haug, G.H., Hughen, K.A., Rohl, U., 2000. Rapid changes in the hydrologic cycle of the tropical Atlantic during the last glacial. Science 290, 1947-1951.

Price, N.B., Calvert, S.E., 1977. Contrasting Geochemical Behaviors of Iodine and Bromine in Recent Sediments from Namibian Shelf. Geochimica et Cosmochimica Acta 41, 1769-1775.

Quinn, W.H., Neal, V.T., 1992. The historical record of El Niño events., In: Bradley, R.S., Jones, P.D. (Eds.), Climate since AD 1500. Routledge, London, pp. 623-648.

Rack, F.R., Heise, E.A., Stein, R., 1995. Magnetic susceptibility and physical properties of sediment cores from Site 893, Santa Barbara Basin: records of sediment diagenesis or of paleoclimatic and paleoceanographic change?, In: Kennett, J.P., Baldauf, J.G., Lyle, M. (Eds.), Proceedings of the Ocean Drilling Program, Scientific Results. Ocean Drilling Program, College Station, TX, pp. 145-168.

Ralph, F.M., Neiman, P.J., Wick, G.A., 2004. Satellite and CALJET aircraft observations of atmospheric rivers over the eastern north pacific ocean during the winter of 1997/98. Monthly Weather Review $132,1721-1745$.

Robert, C., 2004. Late quaternary variability of precipitation in Southern California and climatic implications: clay mineral evidence from the Santa Barbara Basin, ODP site 893. Quaternary Science Reviews 23, 1029-1040.

Rogers, D.J., 1995. A Man, A Dam and A Disaster: Mulholland and the St. Francis Dam. Southern California Quarterly 77, 1-109.

Rohl, U., Bralower, T.J., Norris, R.D., Wefer, G., 2000. New chronology for the late Paleocene thermal maximum and its environmental implications. Geology 28, 927-930.

Schimmelmann, A., Hendy, I.L., Dunn, L., Pak, D., 2013. Revised 2,000-year chronostratigraphy of partially varved marine sediment in Santa Barbara Basin, California. Journal of the Geological Society of Sweden 135, 258-264. 
Schimmelmann, A., Kastner, M., 1993. Evolutionary changes over the last 1000 years of reduced sulfur phases and organic carbon in varved sediments of the Santa Barbara Basin, California. . Geochimica et Cosmochimica Acta 57, 67-78.

Schimmelmann, A., Lange, C.B., 1996. Tales of 1001 varves: a review of Santa Barbara Basin sediment studies. Geological Society, London, Special Publications 116, 121-141.

Schimmelmann, A., Lange, C.B., Berger, W.H., 1990. Climatically Controlled Marker Layers In SantaBarbara Basin Sediments And Fine-Scale Core-To-Core Correlation. Limnology and Oceanography 35, 165-173.

Schimmelmann, A., Lange, C.B., Berger, W.H., Simon, A., Burke, S.K., Dunbar, R.B., 1992. Extreme Climatic Conditions Recorded In Santa-Barbara Basin Laminated Sediments - The 1835-1840 Macoma Event. Marine Geology 106, 279-299.

Schimmelmann, A., Lange, C.B., Roark, E.B., Ingram, B.L., 2006. Resources for paleoceanographic and paleoclimatic analysis: A 6,700-year stratigraphy and regional radiocarbon reservoir-age $(\Delta \mathrm{R})$ record based on varve counting and ${ }^{14} \mathrm{C}$-AMS dating for the Santa Barbara Basin, offshore California, USA. Journal Of Sedimentary Research 76, 74-80.

Schimmelmann, A., Tegner, M.J., 1991. Historical oceanographic events reflected in ${ }^{13} \mathrm{C} /{ }^{12} \mathrm{C}$ ratio of total organic carbon in laminated Santa Barbara Basin sediment. Global Biogeochemical Cycles 5, 173188.

Schimmelmann, A., Zhao, M., Harvey, C.C., Lange, C.B., 1998. A large California flood and correlative global climatic events 400 years ago. Quat. Res. 49, 51-61.

Soutar, A., Crill, P.A., 1977. Sedimentation and climatic patterns in Santa Barbara Basin during the 19th and 20th Centuries. . Geological Society of America Bulletin 88, 1161-1172.

Thornton, S., 1984. Basin model for hemipelagic sedimentation in a tectonically active continental margin: Santa Barbara Basin, California Continental Borderland. Geological Society, London, Special Publications 15, 377-394.

Thornton, S.E., 1986. Origin of mass-flow sedimentary structures in hemispelagic basin deposits - Santa Barbara Basin, California Borderland. Geo-Marine Letters 6, 15-19.

Thunell, R.C., 1998. Particle fluxes in a coastal upwelling zone: sediment trap results from Santa Barbara Basin, California. Deep-Sea Research Part Ii-Topical Studies in Oceanography 45, 1863-1884.

Thunell, R.C., Tappa, E., Anderson, D.M., 1995. Sediment fluxes and varve formation in Santa Barbara Basin, offshore California. Geology 23, 1083-1086.

Tierney, J., Giosan, L., Donnelly, J.P., Shuman, B., Anonymous, 2005. The use of scanning XRF technology in terrestrial paleoclimatology and paleohydrology. Eos, Transactions, American Geophysical Union 86, P14B-02.

Venrick, E.L., 2012. Phytoplankton in the California Current system off southern California: Changes in a changing environment. Progress in Oceanography 104, 46-58. 
Ward, P.J., Eisner, S., Floerke, M., Dettinger, M.D., Kummu, M., 2014. Annual flood sensitivities to El Nino-Southern Oscillation at the global scale. Hydrology and Earth System Sciences 18, 47-66.

Warrick, J.A., DiGiacomo, P.M., Welsberg, S.B., Nezlin, N.P., Mengel, M., Jones, B.H., Ohlmann, J.C., Washburn, L., Terrill, E.J., Farnsworth, K.L., 2007. River plume patterns and dynamics within the Southern California Bight. Continental Shelf Research 27, 2427-2448.

Warrick, J.A., Farnsworth, K.L., 2009a. Dispersal of river sediment in the Southern California Bight, In: Lee, H.J., Normark, W.R. (Eds.), Earth Science in the Urban Ocean: The Southern California Continental Borderland, pp. 53-67.

Warrick, J.A., Farnsworth, K.L., 2009b. Sources of sediment to the coastal waters of the Southern California Bight, In: Lee, H.J., Normark, W.R. (Eds.), Earth Science in the Urban Ocean: The Southern California Continental Borderland, pp. 39-52.

Warrick, J.A., Mertes, L.A.K., 2009. Sediment yield from the tectonically active semiarid Western Transverse Ranges of California. Geological Society of America Bulletin 121, 1054-1070.

Warrick, J.A., Milliman, J.D., 2003. Hyperpycnal sediment discharge from semiarid southern California rivers: Implications for coastal sediment budgets. Geology 31, 781-784.

Warrick, J.A., Xu, J.P., Noble, M.A., Lee, H.J., 2008. Rapid formation of hyperpycnal sediment gravity currents offshore of a semiarid California river. Continental Shelf Research 28, 991-1009. 


\section{Figure 1}

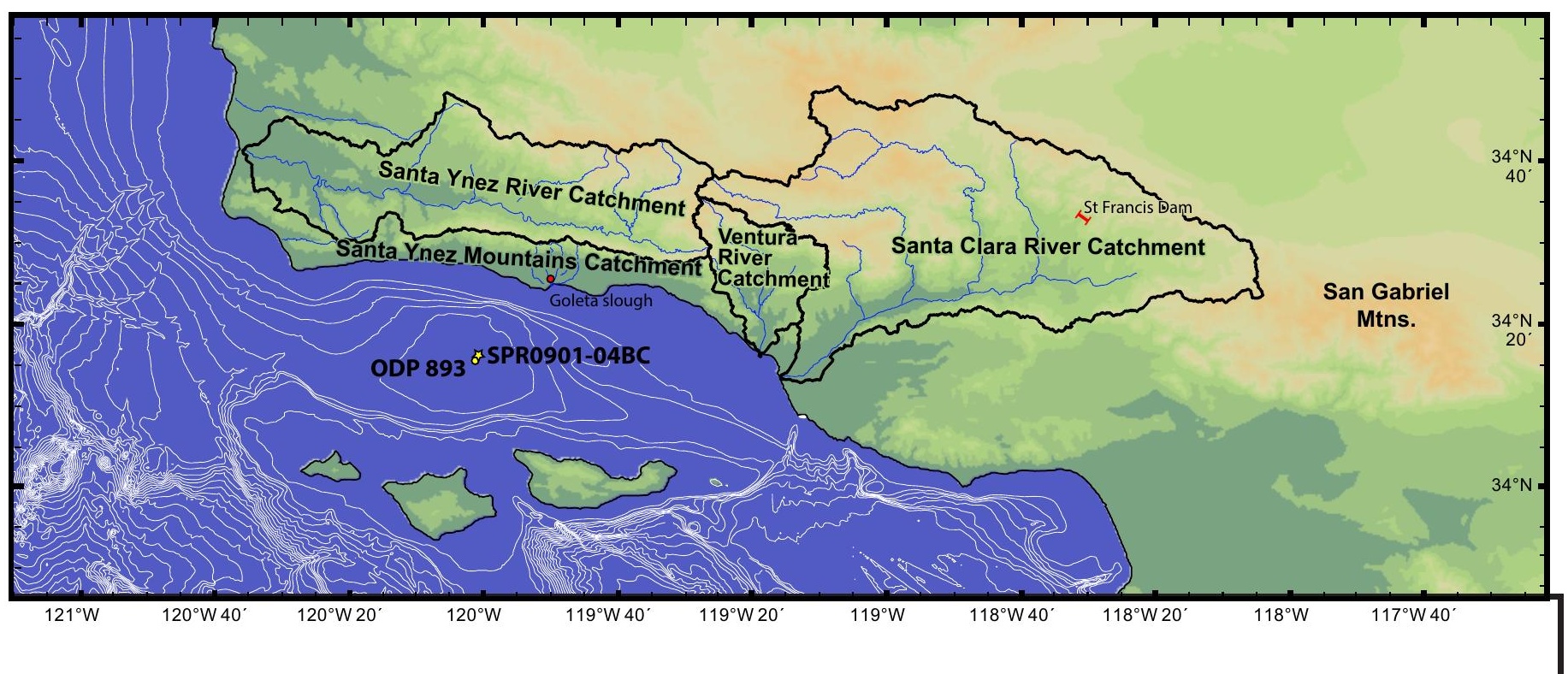


Figure 2

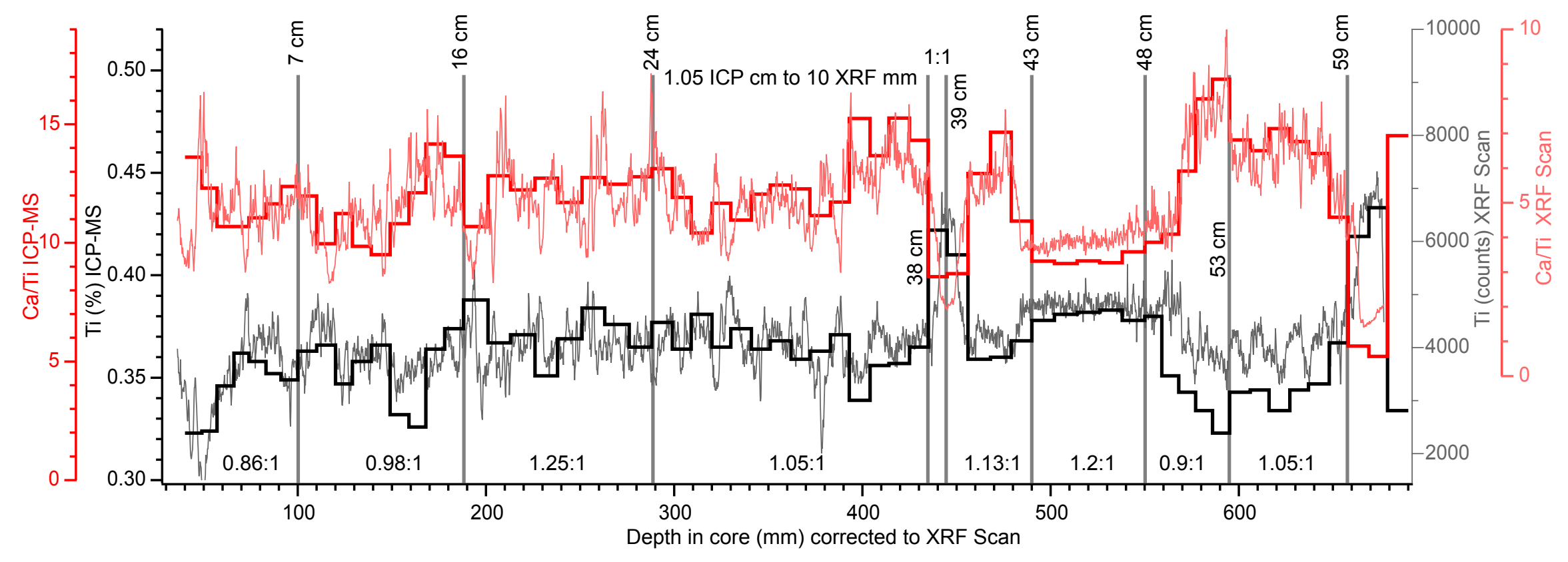


Figure 3

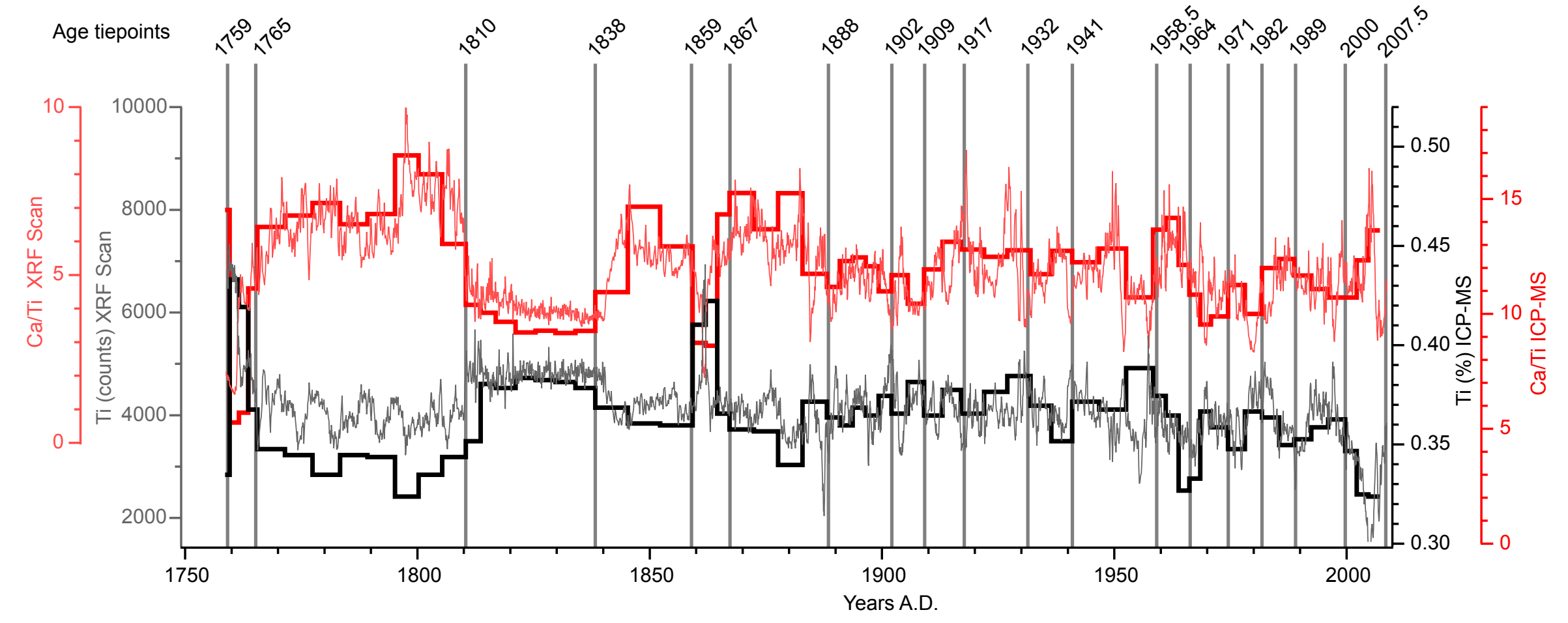


Figure 4

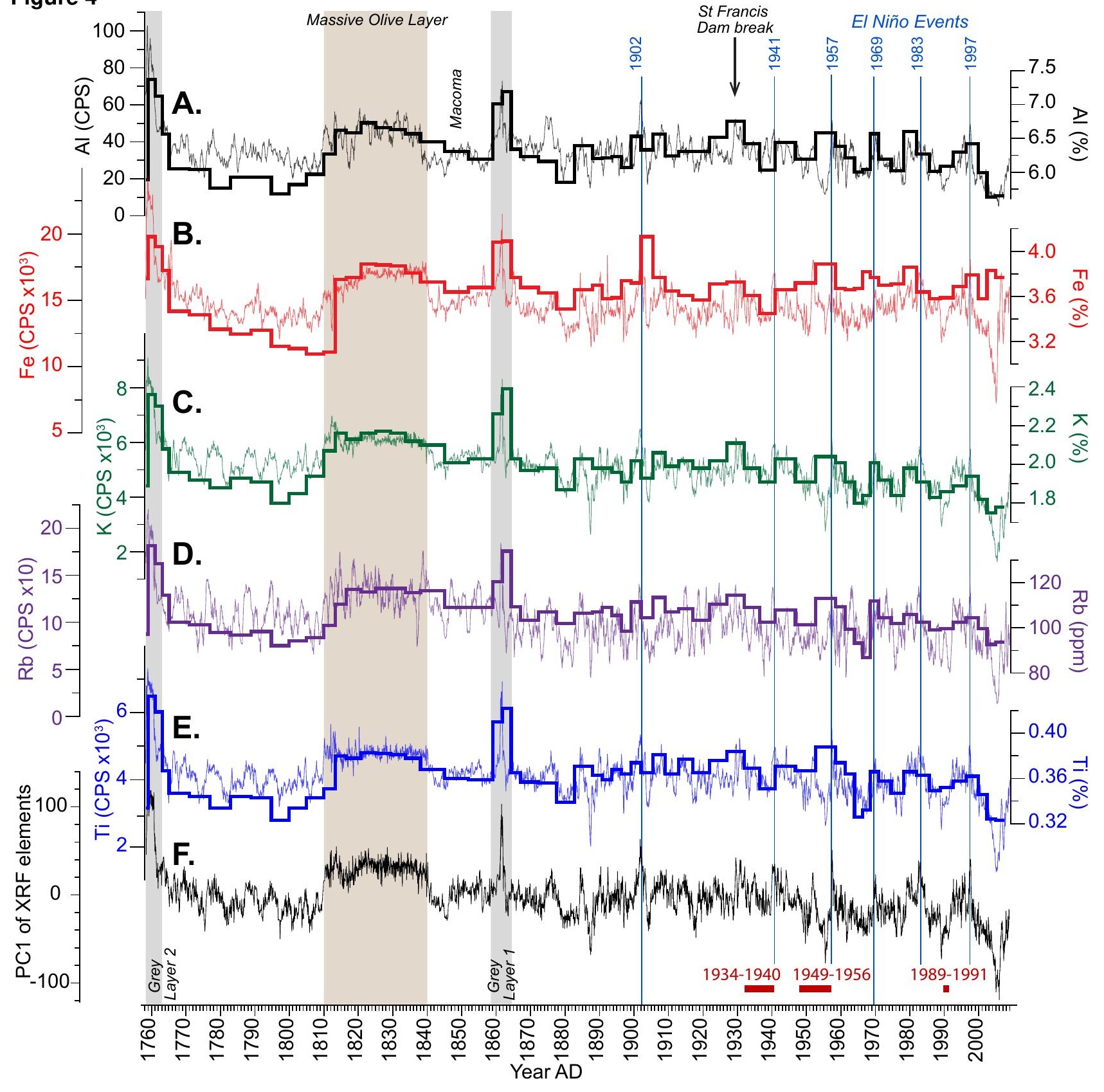




\section{Figure 5}

C $\begin{gathered}\text { Grey } \\ \text { Layer } 2\end{gathered}$

Massive Olive Layer

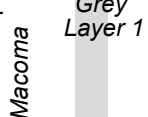

ฮั

El Niño Events

¿ 5

密

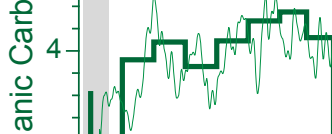

อั $3-$

$A_{s}$

A.

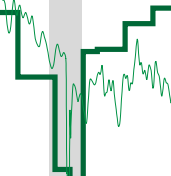

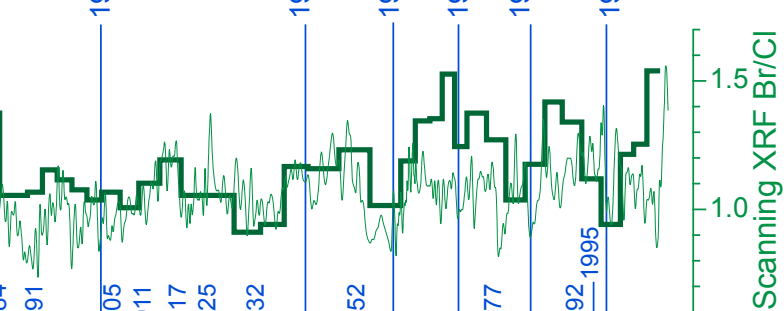

9

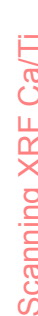
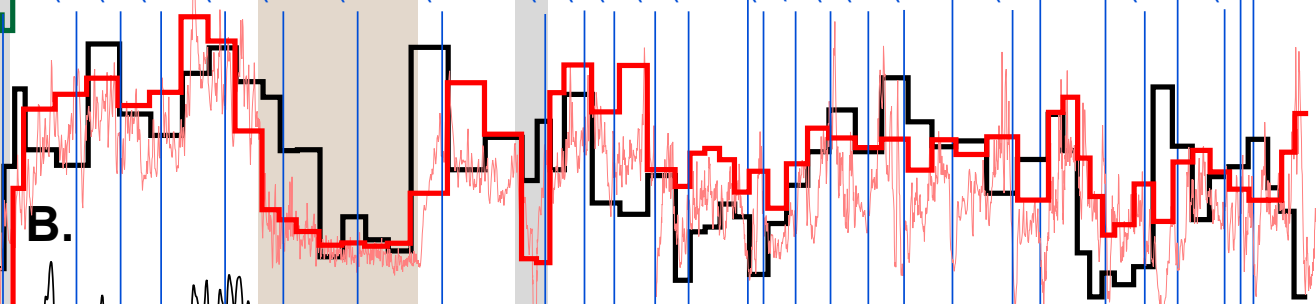

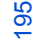

15 당

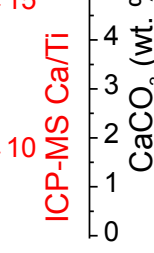

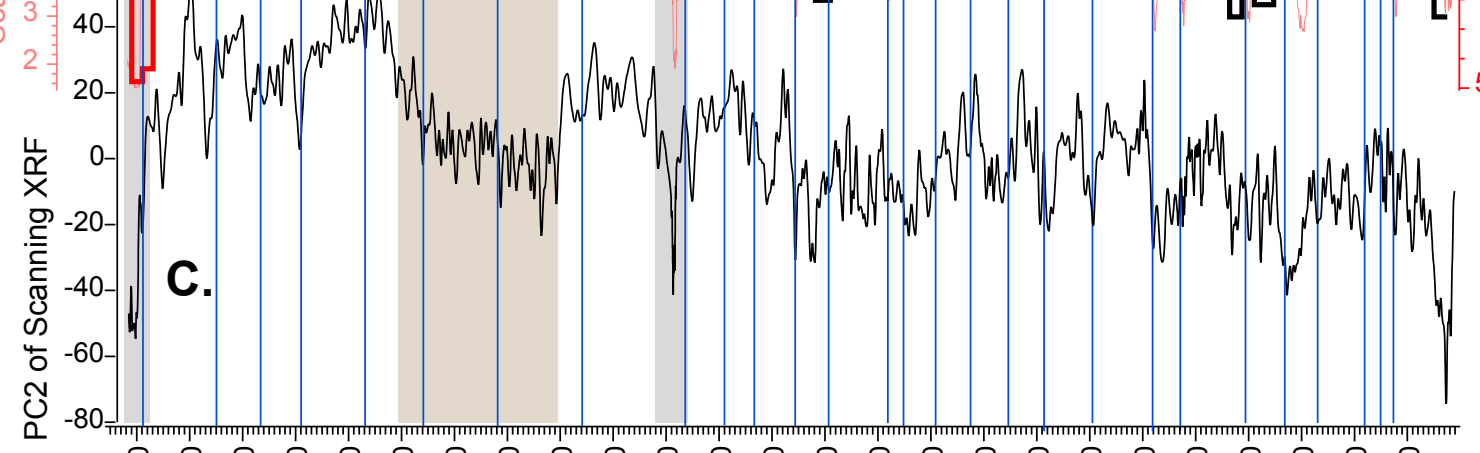

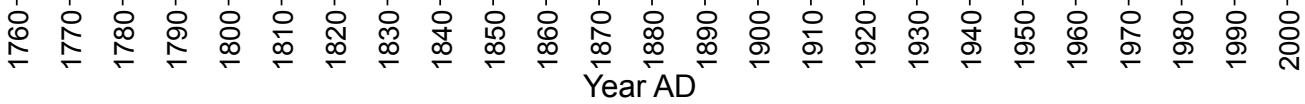




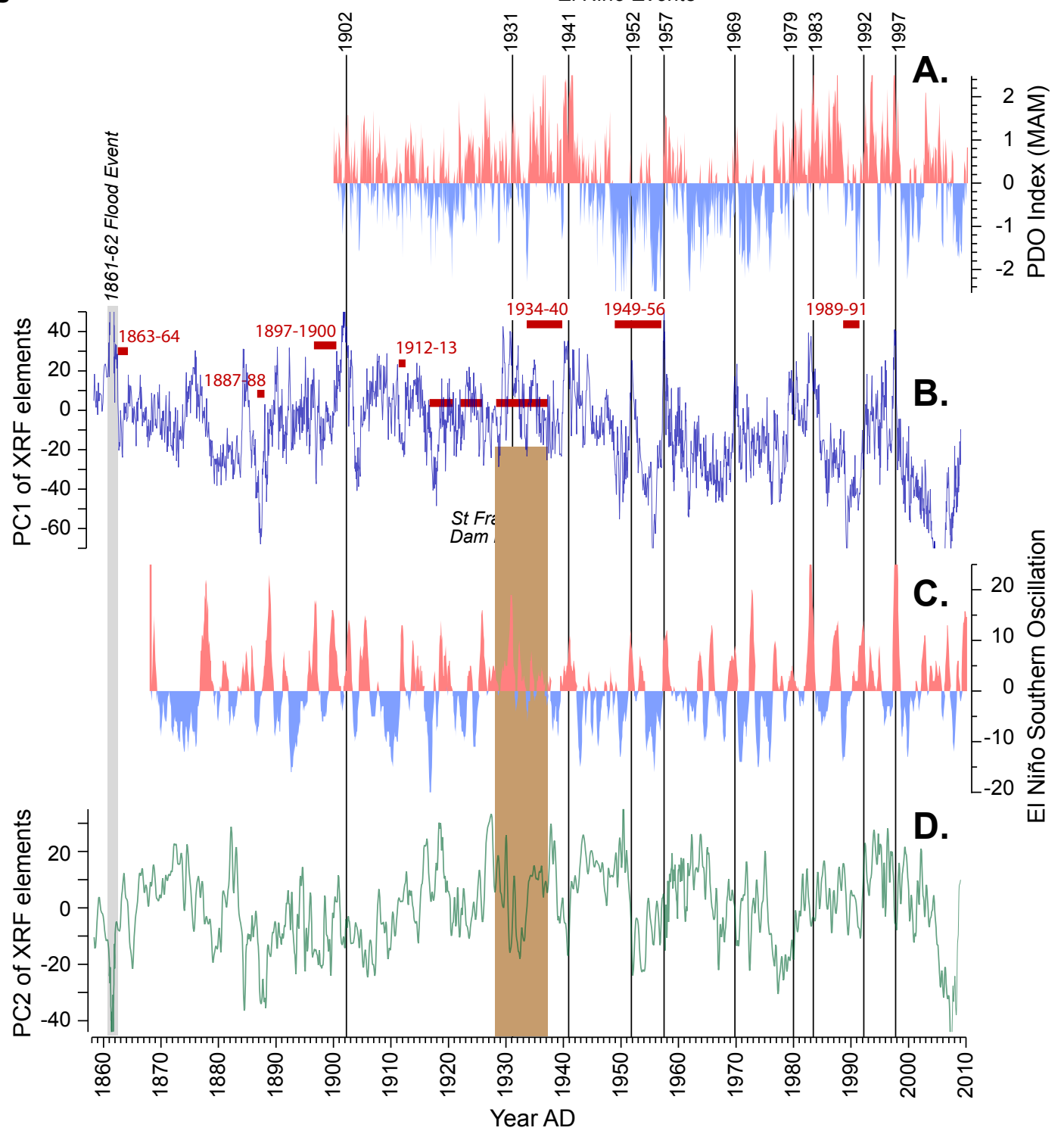

